\title{
Peran Pendidikan Anak Usia Dini Terhadap Fungsi Sosialisasi Dalam Keluarga Di Kelurahan Tadenas Kecamatan Moti
}

\author{
Bahran Taib' ${ }^{1}$ Dewi Mufidatul Ummah², Umikalsum Arfa ${ }^{3}$, Faujia Dati ${ }^{4}$ \\ Universitas Khairun Ternate \\ Jl. Bandara Baabullah Kampus 1 Unkhair, Kelurahan Akehuda Kota Ternate Kode Pos 97728 \\ Email: taibbahar4685@gmail.com
}

\begin{abstract}
Abstrak: Tujuan penelitian ini untuk mengetahui peran pendidikan anak usia dini terhadap fungsi sosialisasi dalam keluarga. Jenis penelitian ini adalah deskripstif kualitatif. Subjek yang dipakai dalam penelitian ini adalah 5 orang tua. Teknik pengumpulan data menggunakan teknik wawancara dan dokumentasi. Data dianalisis dengan menggunakan tahapan reduksi data, menyajikan data, dan menyimpulkan data. Hasil penelitian ini menujukan bahwa peran pendidikan anak usia dini terhadap fungsi sosialisasi sangat penting dikarenakan dengan adanya fungsi sosialisasi dalam keluarga sehingga orang tua dapat mengetahui fungsi agama, fungsi cinta kasih, fungsi sosial budaya, fungsi reproduksi, fungsi ekonomi, fungsi pendidikan dan fungsi lingkungan.
\end{abstract}

Kata kunci : Peran PAUD, Sosialisasi dalam Keluarga, Anak

Abstract: The purpose of this study is to find out the role of early childhood education to the function of socialization in the family. This type of research is descriptive qualitative. The subjects used in this study were 5 parents. Data collection techniques using interview and observation techniques. The data is analyzed using the stages of data reduction, presenting data, and concluding the data. The results of this study show that the role of early childhood education to the function of socialization is very important because of the function of socialization in the family so that parents can know the function of religion, the function of love, socio-cultural functions, reproductive functions, economic functions, educational functions and environmental functions.

Keywords: The Role Of Paud Education, Socialization In The Family, Children

\section{A. Pendahuluan}

Pendidikan adalah usaha sadar yang di lakukan oleh keluarga, masyarakat, dan pemerintah melalui kegiatan bimbingan, pengajaran, dan latihan yang berlangsung di sekolah dan diluar sekolah sepanjang hayat untuk mempersiapkan peserta didik agar dapat mempermainkan peran dalam berbagai lingkungan hidup secara tepat di masa yang akan datang. Pendidikan adalah pengalaman-pengalaman belajar terprogram dalam bentuk pendidikan formal, nonformal, dan informal di sekolah, dan luar sekolah yang berlansung seumur hidup dan bertujuan mengoptimalisasi pertimbangan kemampuankemampuan individu agar dikemudian hari dapat memainkan peran hidup secara tepat.

Keluarga merupakan pusat pendidikan yang pertama dan terpenting. Sejak timbulnya peradaban manusia sampai sekarang, keluarga selalu berpengaruh besar terhadap perkembangan anak. Peranan orang tua bagi pendidikan anak adalah memberikan dasar pendidikan, sikap, dan keterampilan dasar seperti budi pekerti, sopan santun, estetika, kasih sayang, rasa aman, dasar-dasar mematuhi peraturan dan menanamkan kebiasaan-kebiasaan. Pentingnya peranan orang tua dalam pendidikan anak telah disadari oleh banyak pihak. 
Mengasuh, membina dan mendidik anak dirumah merupakan kewajiban bagi setiap orang tua dalam usaha membentuk pribadi anak. Sosialisasi menjadi sangat penting dalam pembentukan kepribadian anak. Lewat sosialisasi yang baik, anak merasa diperhatikan oleh orang tuanya. Sehingga dia mempunyai suatu motivasi dalam membentuk kepribadian yang baik. Berdasarkan hasil pengamatan yang dilakukan oleh peneliti di Kelurahan Tadenas Kecamatan Moti, peneliti menemukan bahwa di Kelurahan Tadenas Kecamatan Moti sudah terdapat PAUD yaitu paud Ngofa Akeboky, namun yang sekolah hanya 8 sampai 10 orang karena orang tua anak disana beranggapan bahwa tidak perlu menyekolahkan anak di PAUD hal ini karena minimnya pengetahuan orang tua tentang pentingnya PAUD dan kurangnya sosialisasi tentang PAUD di masyarakat,. Dan juga fasilitas di PAUD itu sendiri sangat terbatas dan kurangnya guru yang ada di PAUD tersebut. Hal ini juga yang menjadi pertimbangan orang tua untuk menyekolahkan anak mereka di PAUD. Berdasarkan uraian di atas peneliti ingin meneliti tentang." Peran Pendidikan Anak Usia Dini Terhadap Fungsi Sosialisasi dalam Keluarga”.

\section{B. Kerangka Teoretik}

\section{Pentingnya Pendidikan Anak Usia Dini}

Sejak dini, anak harus diberikan berbagai ilmu (dalam bentuk berbagai rangsangan/stimulan). Lebih lanjut, mendidik anak pada usia ini ibarat membentuk ukiran di batu yang tidak akan mudah hilang, bahkan akan membekas selamanya. Artinya, pendidikan pada anak usia dini akan sangat membekas hingga anak dewasa, bahkan sampai si anak tua. Pendidikan pada usia ini adalah peletak dasar bagi pendidikan anak selanjutnya. Dengan ungkapan lain keberhasilan pendidikan usia dini ini sangat berperan besar bagi keberhasilan anak di masa-masa selanjutnya.

Harus dingat bahwa fungsi PAUD bukan sekedar memberikan berbagai pengetahuan melainkan tidak kalah pentingnya adalah untuk mengajak anak berfikir, bereksplorasi, bergaul, brekspresi, serta berbagai hal yang dapat merangsang pertumbuhan. Pendidikan Anak Usia Dini bertujuan untuk mengembangkan seluruh potensi anak agar kelak dapat berfungsi sebagai manusia yang utuh sesuai dengan falsafah suatu bangsa. Anak dapat dipandang sebagai individu yang sopan santun, aturan,norma, ertika, dan berbagai hal tentang dunia. Anak perlu bimbingan agar mampu memahami berbagai hal tentang dunia dan isinya. Ia juga perlu dibimbing agar memahami berbagai fenomena alam dan dapat melakukan ketrampilan-keterampilan yang dibutuhkan untuk hidup di masyarakat. (Ermidawati,2011).

Solehuddin (1997), bahwa tujuan pendidikan anak usia dini adalah memfasilitasi pertumbuhan dan perkembangan anak secara optimal dan menyeluruh sesuai dengan norma dan nilai-nilai kehidupan yang dianut. Melalui pendidikan anak usia dini, anak diharapkan dapat mengembangkan segenap potensi yang di milikinya yakni intlektual, sosial, emosi, dan fisik-motorik. Selain itu satu aspek yang tidak boleh ditinggalkan adalah perkembangan rasa beragama sebagai dasar-dasar aqidah yang lurus sesuai dengan ajaran yang dianutnya,memiliki kebiasan atau perilaku yang diharapkan menguasai sejumlah pengetahuan dan ketrampilan dasar sesuai dengan kebutuhan dan tingkat perkembangan serta memiliki motivasi dan sikap belajar yang positif. 


\section{Peran Keluarga dalam Pendidikan Anak Usia Dini}

Keluarga adalah kelompok primer yang paling penting di dalam masyarakat. Keluarga merupakan sebuah kelompok yang terbentuk hubungan antara laki-laki dan perempuan yang berlangsung lama untuk mnciptakan dan membesarkan anak. Jadi keluarga dalam bentuk murni merupakan lingkungan terdekat bagi anak sejak anak dilahirkan. Di dalam keluarga anak memperoleh banyak pengalaman dan stimulus untuk tumbuh dan berkembang. (Chawahyudi, 2005).

Keluarga juga merupakan lingkungan terdekat anak dan tempat belajar yang paling baik buat anak. Di keluarga, anak bisa belajar selaras dengan keinginannya sendiri. Ia tak perlu duduk menunggu sampai bel berbunyi, tidak perlu harus bersaing dengan anak-anak lain, tidak perlu harus ketakutan menjawab salah di depan kelas, dan bisa langsung mendapatkan penghargaan atau pembetulan kalau membuat kesalahan. Di sinilah peran orang tua menjadi sangat penting, karena tugas utama orangtua sebetulnya adalah pengatur rumah tangga dan pendidik anak.

Keluarga memiliki peranan utama didalam mengasuh anak, di segalah norma dan etika yang berlaku didalam lingkungan masyarakat. Keluarga kembali mengambil peranan penting dalam peningkatan kualitas sumber daya manusia. Peran orang tua dalam keluarga sangat penting dalam menanamkan pendidikan anak untuk menghadapi tantangan dunia baik diluar lingkungan keluarga ,maka setiap keluarga harus dapat memberikan pemahaman kepada anak dalam konteks kehidupannya untuk dapat berinteraksi dengan semua orang di sekitarnya.

\section{Fungsi Sosialisasi dalam Keluarga}

Fungsi sosialisasi keluaga tercermin dalam melakukan pembinaan sosialisasi pada anak, membentuk nilai dan norma yang di yakini anak, memberikan batasan perilaku yang boleh dan tidak boleh pada anak, meneruskan nilai-nilai budaya keluarga. Bagaimana keluarga produktif terhadap sosial dan bagaimana keluarga memperkenalkan anak dengan dunia luar dengan belajar disiplin mengenai budaya dan norma melalui hubungan interaksi dalam keluarga sehingga mampu berperan dalam masyarakat. (Arinda, 2014).

Fungsi sosialisasi keluarga menurut BKKBN ada delapan fungsi yaitu (http://kalteng.bkkbn.go.id/rubrik/35/):

a. Fungsi agama

Sebagai sarana awal memperkenalkan nilai-nilai religius kepada anggota keluarga baru. Dalam proses sosialisasi ini, interaksi antar anggota keluarga berlangsung secara intens.

b. Fungsi sosial budaya

Fungsi ini ditanamkan bertujuan untuk memberikan identitas sosial kepada keluarga itu,termasuk anggota keluarga baru. Budaya diwariskan awalnya dalam institusi ini.

c. Fungsi cinta kasih

Dalam keluarga idealnya terdapat "kehangatan". 


\section{d. Fungsi perlindungan}

Sifat dasar dari setiap individu adalah bertahan terhadap segala gangguan dan ancaman.Dalam hal ini keluarga berperan sebagai benteng terhadap seluruh anggota keluarga dari gangguan fisik maupun psikis.

e. Fungsi reproduksi

Keberlangsungan keluarga dilanjutkan melalui proses regenerative, dalam hal ini keluarga adalah wadah yang sah dalam melanjutkan proses regenerasi itu.

f. Fungsi pendidikan

Sebagai wadah sosialisasi primer, keluargalah yang mendidik dan menanmkan nilai-nilai dasar. Ketika proses itu berjalan, perlahan-lahan institusi lain (sekolah) akan mengambil peranan sebagai wadah sosialisasi sekunder.

g. Fungsi ekonomi

Kesejahteraan keluarga akan tercapai dengan berfungsinya dengan baik fungsi ekonomi ini.Keluargalah yang memenuhi kebutuhan-kebutuhan sehari-hari anggota keluarganya.

h. Fungsi lingkungan

Fungsi ini erat kaitannya dengan hubungan dengan lingkungan sekitar. Lingkungan yang harmonis merupakan kondisi apabila dimana dalam fungsinya setiap keluarga bisa meyakinkan anggota keluarganya untuk bisa menjaga dan melihat lingkungan sekitarnyan dengan baik.

Fungsi sosialisasi dalam keluarga bertujuan untuk mendidik anak mulai dari awal sampai pertumbuhan anak hingga terbentuk personalitynya. Anak-anak itu lahir tanpa bekal sosial, agar anak dapat berpartisipasi orang tua memiliki kewajiban untuk mensosialisasikan nilai-nilai yang ada pada masyarakat. Dalam keluarga anak mendapatkan pengarahan dari cara berprilaku, bersikap dan bertindak sesuai dengan nilai dan norma yang berlaku. Sebab itulah keluarga merupakan pelantara diantara masyarakat luas dan individu. Perlu diketahui bahwa kepribadian seseorang itu diletakan pada waktu yang sangat muda dan yang berpengaruh besar sekali terhadap kepribadian seseorang adalah keluarga (J.Dwi Narwoko dkk, 2011).

\section{Dampak Fungsi Sosialisasi dalam Keluarga}

Keluarga menjadi kelompok sosial utama tempat anak atau anggota keluarga belajar menjadi manusia sosial. Rumah tangga menjadi tempat pertama dalam perkembangan segi-segi sosialnya dan dalam intraksi dibangun dengan wajar, ia pun memperoleh bekal yang memungkinkan untuk menjadi anggota masyarakat yang berguna kelak. Apabila hubungan dalam keluarga kurang baik maka besar kemungkinan interaksi sosisal pun tidak berlangsung secara baik, sehingga interaksi konflik yang terjadi dalam adalah interaksi yang sifatnya verbal sampai kepada yang bersifat fisik. (Rustina, 2014).

Ahmadi dan Supriyono menambahkan bahwa tugas dan fungsi keluarga merupakan fungsi yang tunggal tapi jamak. Dalam hal ini fungsi keluarga dibagi menjadi tiga bagian secara sederhana diantaranya menstabilisasi situasi keluarga dalam artian stabilisasi ekonomi rumah tangga dan mendidik anak yakni pemeliharaan fisik dan psikis keluarga termasuk disini kehidupan religus. Perubahan situasi seringkali terjadi baik dalam keluarga maupun di masyarakat dan efeknya 
akan berpengaruh terhadap berbagai dimensi kehidupan manusia bahwa perubahan sosial yang terjadi telah merubah fungsi-fungsi dari keluarga kepada lembaga-lembaga yang lain.

Keluarga yang mengalami dampak dari fungsi sosialisasi sangat berpengaruh pada sosialisasinya dalam keluarga, karena dampak dari fungsi tersebut keluarga merupakan suatu hal yang disebabkan gagalnya keluarga dalam menjalankan fungsi sosialisasi yang seharusnya dilakukan oleh keluarga tetapi dijalankan oleh orang lain atau lembaga lain. Menurut Ogburn, adanya perubahan dalam fungsi keluarga di yang memperlihatkan dalam detail statistik bahwa aktifitas di dalam keluarga seperti ekonomi, perlindungan, pendidikan dan agama telah beralih secara pesat kepada badan-badan di luar keluarga. (Khoiruddin, 2008).

Sebagai sebuah system, keluarga dapat terpecah apabila salah satu atau lebih anggota keluarga tidak menjalankan tugas dan fungsinya dalam keluarga hingga menyebabkan terjadinya keluarga yang tidak harmonis dan tentu akan mempengaruhi keutuhan keluarga sebagai sebuah sistem. Hal ini dapat diartikan sebagai fungsi keluarga tidak dapat berjalan dengan normal sebagaimana mestinya, selain itu juga hubungan yang terjalin di dalamnya tidak berjalan dengan harmonis, seperti fungsi masing-masing anggota keluarga tidak jelas atau ikatan emosi antar anggota keluarga kurang terjalin dengan baik. (Siswanto, 2007).

\section{Metode Penelitian}

Jenis penelitian yang digunakan adalah penelitian deskriptif kualitatif. Penelitian ini dilakukan untuk mendeskripsikan tentang peran pendidikan anak usia dini terhadap fungsi sosialisasi dalam keluarga di Kelurahan Tadenas Kecamatan Moti. Penelitian ini bertempat di Kelurahan Tadenas Kecamatan Moti dengan Waktu penelitian yang direncanakan selama 4 bulan dimulai dari bulan November 2020 sampai bulan Februari 2021. Subjek dalam penelitian ini adalah orang tua dengan jumlah 5 orang tua dari peserta didik di PAUD Nyofa Akeboky. Peneliti mengambil 5 subjek dalam penelitian ini dengan alasan bahwa mereka adalah orang tua dari anak yang bersekolah di PAUD Ngofa Akeboky.

\section{Peran Pendidikan Anak Usia Dini Terhadap Fungsi Sosialisasi Dalam Keluarga}

Penelitian ini membahas tentang peran pendidikan anak usia dini terhadap fungsi sosialisasi dalam keluarga di Kelurahan Tadenas Kecamatan Moti. Paparan ini merupakan hasil penelitian secara langsung yang didapatkan peneliti secara langsung darii hasil wawancara ke tempat penelitian. Kegiatan wawancara yang dilakukan oleh peneliti dengan menggunakan pedoman wawancara yang didalamnya memuat indikator-indikator yaitu 1) fungsi agama, 2) fungsi sosial budaya, 3) fungsi cinta kasih, 4) fungsi perlindungan, 5) fungsi reproduksi, 6) fungsi pendidikan, 7) fungsi ekonomi, 8) fungsi lingkungan. Adapun hasil dari penelitian tersebut dapat dideskripsikan sebagai berikut :

\section{Fungsi Agama}

Melalui kegiatan wawancara yang dilakukan oleh peneliti, nilai -nilai religius di paud adalah sebagai awal dari meningkatkan nilai-nilai keagamaan pada anak 
sehingga nilai religius sangat penting untuk di terapkan sejak dini, perlu untuk menanamkan nillai agama di PAUD karena dengan menanamkan nilai agama sejak dini anak akan lebih mengetahui pentingnya spiritual bagi masa depannya dan juga dapat membedakan mana yang baik dan mana yang buruk.

\section{Fungsi Sosial Budaya}

Sikap anak di kelurahan tadenas saat berkomunikasi dengan orang lain ada yang selalu menjaga perkataanya dengan baik terutama sebutan nama atau panggilan yang lebih cocok untuk orang yang lebih tua adapun anak yang suda paham dengan baik apa yang orang bilang namun terkdang ada anak yang juga sering mengeluarkan bahasa yang bisa dibilang tidak pantas atau dalam artian bahasa yang kasar dan komunikasi yang dilakukan dalam keluarga biasanya berbicara dengan bahasa-bahasa yang sopan dan tidak membentak dan saling menghargai orang lain.

Berdasarkan hasil wawancara yang dilakukan bahwa dapat disimpulkan bahwa sikap anak di keluarahan Tadenas saat berkomunikasi dengan orang lain ada yang selalu menjaga perkataanya dengan baik terutama sebutan nama atau panggilan yang lebih cocok untuk orang yang lebih tua adapun anak yang suda paham dengan baik apa yang orang bilang namun terkadang ada anak yang juga sering mengeluarkan bahasa yang bisa dibilang tidak pantas atau dalam artian bahasa yang kasar.

\section{Fungsi Cinta Kasih}

Kasih sayang yang diterapkan dalam keluarga yaitu membimbing anak dengan baik dan ajarkan mereka bagaimana caranya anak menyayangi orang tua, serta menghormati kakak dan menyayangi adik ada juga yang menjelaskan bahwa menjaga anak adalah salah satu bentuk dari kasih sayang.

Berdasarkan hasil Wawancara, dapat disimpulkan bahwa kasih sayang yang diterapkan dalam keluarga yaitu membimbing anak dengan baik dan ajarkan mereka bagaimana caranya anak menyayangi orang tua, serta menghormati kakak dan menyayangi adik ada juga yang menjelaskan bahwa menjaga anak adalah salah satu bentuk dari kasih sayang.

\section{Fungsi Perlindungan}

Orang tua paham bahwa kekerasan tidak bisa diperlihatkan kepada anak karena akan berdampak buruk pada gangguan tumbuh kembang yang sedang di alami oleh anak tersebut dan juga dapat menggangu psikologi anak. Ada pula yang sering bahkan pernah melakukan kekerasan di depan anak mereka yang secara langsung dapat menggangu psikologi anak tersebut.

Berdasarkan hasil wawancara di atas dapat di simpulkan bahwa orang tua di kelurahan Tadenas paham bahwa kekerasan tidak bisa diperlihatkan kepada anak karena akan berdampak buruk pada gangguan tumbuh kembang yang sedang di alami oleh anak tersebut dan juga dapat menggangu psikologi anak dan jika kekerasan itu dilaukukan maka akan berdampak pada anak di masa tuanya

\section{Fungsi Reproduksi}

Di kelurahan Tadenas pendidkan seks sudah di ajarkan sejak dini di dalam keluarga dimana ketika bermain dengan teman yang lawan jenis maka jangan memukul dan memegang pada bagian-bagian tertentu. Orang tua mengajarkan pendidikan seks pada anaknya dengan cara memberitahukan kepada anak bagian- 
bagian tubuh tertentu yang tidak boleh di sentuh orang lain, adapun orang tua yang mengajarkan kepada anaknya untuk tetap memakai pakaian saat mandi tempat terbuka itu semua bentuk dari ketegasan orang tua dalam mengajarkan pendidikan seks pada anak.

Berdasarkan hasil wawancara dari 5 responden diatas bahwa orang tua mengajarkan pendidikan seks pada anaknya dengan cara memberitahukan kepada anak bagian -bagian tubuh tertentu yang tidak boleh di sentuh orang lain, adapun orang tua yang mengajarkan kepada anaknya untuk tetap memakai pakaian saat mandi tempat terbuka itu semua bentuk dari ketegasan orang tua dalam mengajarkan pendidikan seks pada anak.

\section{Fungsi Pendidikan}

Keberadaan lembaga PAUD sangat penting dimana suatu lembaga yang memberikan layanan pengasuhan pendidikan dan pengembangan bagi anak usia dini, juga sangat membantu orang tua dalam memberikan pelajaran dirumah yang belum efektif sehingga lembaga PAUD menjadi pendidikan lanjutan dari keluarga. Pendidikan untuk anak sangat penting karena pendidikan merupakan pondasi yang akan membentuk masa depan anak.

Berdasarkan hasil wawancara di atas dapat disimpulkan bahwa pendidikan untuk anak sangat penting karena pendidikan merupakan pondasi yang akan datang.

\section{Fungsi Ekonomi}

Orang tua dalam menerapkan perilaku berhemat kepada anak dengan cara membiaskan anak untuk menabung sejak dini, karena dengan cara tersebut anak akan lebih menghemat uang dari pada membeli jajan, ada juga orang tua yang lebih memilih memberikan bekal setiap ke sekolah guna untuk mengajarkan perilaku berhemat kepada anak.

Berdasarkan hasil wawancara diatas dapat disimpulkan bahwa cara orang tua menerapkan perilaku berhemat kepada anak dengan cara membiaskan anak untuk menabung sejak dini, karena dengan cara tersebut anak akan lebih menghemat uang dari pada membeli jajan, ada juga orang tua yang lebih memilih memberikan bekal setiap ke sekolah guna untuk mengajarkan perilaku berhemat kepada anak.

\section{Fungsi Lingkungan}

Lingkungan kelurahan Tadenas sangat mendukung perkembangan anak dimana lingkungan sekitar dapat membentuk perilaku anak, serta sangat mendukung perkembangan anak karena lingkungan sangat berpengaruh pada perkembangan karakter anak jika anak tumbuh di lingkungan yang baik maka anak pun akan berkembang menjadii anak yang baik, ada juga orang tua menjelaskan bahwa ada sisi negatif dari lingkungan sekitar oleh karena itu orang tua perlu mengontrol lingkungan bermain anak.

Nilai-nilai religius di PAUD adalah sebagai awal dari meningkatkan nilai-nilai keagamaan pada anak sehingga nilai religius sangat penting untuk di terapkan sejak dini, perlu untuk menanamkan nillai agama di PAUD karena dengan menanamkan nilai agama sejak dini anak akan lebih mengetahui pentingnya spiritual bagi masa depannya dan juga dapat membedakan mana yang baik dan mana yang buruk. Hal ini didukung oleh pendapat ( Sutarmin dkk, 2014) bahwa Pendidikan nilai, melalui penanaman nilai-nilai 
dasar religius secara informal memang menjadi kewajiban keluarga dalam bentuk sosialisasi primer secara umum dalam bentuk sosialisasi. Penanaman nilai-nilai religius yang fungsinya mendasari perilaku anak di luar rumah yang telah dilaksanakan oleh keluarga.

Sikap anak di Kelurahan Tadenas saat anak berkomunikasi dengan orang lain ada yang selalu menjaga perkataanya dengan baik terutama sebutan nama atau panggilan yang lebih cocok untuk orang yang lebih tua adapun anak yang suda paham dengan baik apa yang orang bilang namun terkadang ada anak yang juga sering mengeluarkan bahasa yang bisa dibilang tidak pantas atau dalam artian bahasa yang kasar dan komunikasi yang dilakukan dalam keluarga biasanya berbicara dengan bahasa-bahasa yang sopan dan tidak membentak dan saling menghargai orang lain. Hal ini sejalan dengan pendapat (Ermidawati, 2011) bahwa Anak Usia Dini bertujuan untuk mengembangkan seluruh potensi anak agar kelak dapat berfungsi sebagai manusia yang utuh sesuai dengan falsafah suatu bangsa. Anak dapat dipandang sebagai individu yang sopan santun, aturan, norma, etika, dan berbagai hal tentang dunia. Anak perlu bimbingan agar mampu memahami berbagai hal tentang dunia dan isinya. Ia juga perlu dibimbing agar memahami berbagai fenomena alam dan dapat melakukan keterampilan-keterampilan yang dibutuhkan untuk hidup di masyarakat.

Kasih sayang yang diterapkan dalam keluarga yaitu membimbing anak dengan baik dan ajarkan mereka bagaimana caranya anak menyayangi orang tua, serta menghormati kakak dan menyayangi adik ada juga yang menjelaskan bahwa menjaga anak adalah salah satu bentuk dari kasih sayang. Hal ini sejalan dengan pendapat dari (Sumarni, 2014 ) bahwa kasih sayang memiliki peran penting dalam mendukung tumuh kembang anak, hal ini dikarenakan kasih sayang berkonstribusi dalam kelangsungan hidup jangka panjang, maka orang tua orang tua harus memberikan lebih banyak kasih sayang pada anak-anaknya.

Di Kelurahan Tadenas pendidkan seks sudah di ajarkan sejak dini di dalam keluarga dimana ketika bermain dengan teman yang lawan jenis maka jangan memukul dan memegang pada bagian-bagian tertentu. Orang tua mengajarkan pendidikan seks pada anaknya dengan cara memberitahukan kepada anak bagian-bagian tubuh tertentu yang tidak boleh di sentuh orang lain, adapun orang tua yang mengajarkan kepada anaknya untuk tetap memakai pakaian saat mandi tempat terbuka itu semua bentuk dari ketegasan orang tua dalam mengajarkan pendidikan seks pada anak. Hal ini didukung oleh pendapat (seli noratih, 2016) bahwa orang tua adalah sebagai tempat belajar utama bagi anak, maka dari orang tua yang paling tepat untuk memberikan pendidikan seks pada anak usia dini. Pendidikan seks anak usia dini bukan berarti mengajarkan bagaimana cara melakukan seks . Namun pendidikan seks pada anak usia dini menjelaskan tentang orangorgan yang dimiliki manusia dan fungsinya.

Orang tua di kelurahan Tadenas paham bahwa kekerasan tidak bisa diperlihatkan kepada anak karena akan berdampak buruk pada gangguan tumbuh kembang yang sedang di alami oleh anak tersebut dan juga dapat menggangu psikologi anak. Ada pula yang sering bahkan perna melakukan kekerasan di depan anak mereka yang secara langsung dapat menggangu psikologi anak tersebut. Hal ini mengacu pada pendapat (Nuraeni, 2017) bahwa orang tua dan guru beranggapan bahwa kekerasan pada anak 
hanya bersifat fisik, padahal kekerasan pada anak tidak hanya selalu bersifat fisik atau seksual, tetapi verbal dan emosional juga mengarah pada kekerasan sehingga dapat mengakibatkan anak jadi mengucapkan kata-kata kasar dan tidak menghargai orang lain.

Keberadaan lembaga PAUD sangat penting dimana suatu lembaga yang memberikan layanan pengasuhan pendidikan dan pengembangan bagi anak usia dini, juga sangat membantu orang tua dalam memberikan pelajaran dirumah yang belum efektif sehingga lembaga PAUD menjadi pendidikan lanjutan dari keluarga. Pendidikan untuk anak sangat penting karena pendidikan merupakan pondasi yang akan membentuk masa depan anak. Hal ini di dukung oleh (Solehuddin ,1997) bahwa tujuan pendidikan anak usia dini adalah memfasilitasi pertumbuhan dan perkembangan anak secara optimal dan menyeluruh sesuai dengan norma dan nilai-nilai kehidupan yang dianut. Melalui pendidikan anak usia dini, anak diharapkan dapat mengembangkan segenap potensi yang di milikinya yakni intlektual, sosial, emosi, dan fisik-motorik. Selain itu satu aspek yang tidak boleh ditinggalkan adalah perkembangan rasa beragama sebagai dasar-dasar aqidah yang lurus sesuai dengan ajaran yang dianutnya, memiliki kebiasan atau perilaku yang diharapkan menguasai sejumlah pengetahuan dan keterampilan dasar sesuai dengan kebutuhan dan tingkat perkembangan serta memiliki motivasi dan sikap belajar yang positif.

Orang tua menerapkan perilaku berhemat kepada anak dengan cara membiaskan anak untuk menabung sejak dini, karena dengan cara tersebut anak akan lebih menghemat uang dari pada membeli jajan, ada juga orang tua yang lebih memilih memberikan bekal setiap ke sekolah guna untuk mengajarkan perilaku berhemat kepada anak. Hal ini sejalan dengan pendapat (Mohamad Masrun, 2013) bahwa perilaku hemat adalah sikap hati-hati dan teratur dalam mengatur dan membelanjakan uang dan memiliki tujuan mempersiapkan bekak untuk masa depan anak.

Lingkungan kelurahan Tadenas sangat mendukung perkembangan anak dimana lingkungan sekitar dapat membentuk perilaku anak, serta sangat mendukung perkembangan anak karena lingkungan sangat berpengaruh pada perkembangan karakter anak jika anak tumbuh di lingkungan yang baik maka anak pun akan berkembang menjadi anak yang baik. Hal ini senada dengan pendapat dari (Menurut Weni haluti, 2015) bahwa lingkungan keluarga dapat berperan penuh terhadap perkembangan keluarganya untuk memberikan system pendidikan secara komperhensif, saling berkesinambungan, mulai dari anak tumbuh dari masa perkembangan sampai masuk kedewasaan, dengan demikian keadaan keluarga yang sibuk di luar rumah, sulit memperhatikan perkembangan anaknya yang mengakibatkan banyak anak mengalami problem dan justru pengaruhnya dari lingkungan masyarakat.

\section{E. Simpulan}

Berdasarkan hasil penelitian yang dilakukan oleh peneliti di Kelurahan Tadenas Kecamatan Moti pada 5 subjek yang merupakan orang tua dari peserta didik untuk mengetahui peran PAUD terhadap fungsi sosialisasi dalam keluarga dan dampak keberadaan lembaga PAUD terhadap fungsi sosialisasi dalam keluarga dapat di simpulkan bahwa peran PAUD sangat berpengaruh terhadap fungsi sosialisai dalam keluarga dimana orang tua dapat mengetahui pentingnya keberadaan lembaga PAUD karena adanya PAUD 
dapat memberikan layanan pengasuhan dan pengembangan bagi anak usia dini dan dapat membantu orang tua memberikan pelajaran di rumah yang belum efektif

Berdasarkan hasil penelitian ini dapat disimpulan bahwa dalam serial animasi Upin dan Ipin terdapat lima pola perilaku sosial pada episode Cerita Kami bagian kedua season 5, Indahnya Syawal bagian pertama dan kedua season 10, Ikhlas Dari Hati bagian pertama dan kedua season 5 dan Untuk Prestasi bagian pertama sampai ketiga season 12 . Lima pola perilaku sosial tersebut kerja sama, kemurahan hati, simpati, sikap ramah dan sikap tidak mementingkan diri sendiri. Pada kelima pola perilaku tersebut sangat berpengaruh penting untuk perkembangan perilaku sosial anak usia dini. Perkembangan perilaku sosial anak usia dini adalah bagaimana anak usia dini berinteraksi dengan teman sebaya, orang dewasa dan masyarakat luas agar dapat menyesuaikan diri dengan baik.

\section{DAFTAR PUSTAKA}

Arifin A. 2017. Bimbingan Dan Konselin Anak Usia Dini. Makasar. Mitra Edukasi. Makasar.

Asef Umar Fakhruddin.2009. Pendidikan Anak Usia Dini sebagai Alas Pendidikan Jurnal Pemikiran Arternatif Kependidikan. Purwakerto.

Cintya Nurika Irma Dkk. 2019. Keterlibatan Orang Tua dalam Pendidikan Anak Usia Dini. Jurnal Pendidikan Anak Usia Dini. Vol 3.

Drs.L.S. Sulo La.\&Prof.Dr.Umar Tirtarahardja 2015. Pengantar Pendidikan. Jakarta.: Rineka Cipta.

Ermidawati. 2011. Peran Keluarga Dalam Pendidikan Anak Usia Dini. Jurnal Keluarga Sehat Sejahtera. Vol 9.

Eko Setiyawan.2012. Disfungsi Sosialisa Dalam Keluarga Sebagai Dampak Keberadaan Pendidikan Anak Usia Dini. Vol 1 Yogyakarta

Ihromi, 2004. Disfungsi Sosialisasi Dalam Keluarga Sebagai Damapak Keberadan Pendidikan Anak Usia Dini.Jurnal Pendidikan Sosiologi Dan Sejarah., Hal. 30-32. Yogyakarta.

Novrinda Dkk. 2017. Peran Orang Tua Dalam Pendidikan Anak Usia Dini. Jurnal Potensial Pendidikan Anak Usia Dini. Vol 2. Vol 1. Bengkulu.

Raihana. 2018. Urgensi sekolah paud untuk tumbuh kemabng anak. Jurnal pendidikan anak usia dini. Vol 1. No 1. Riau

Rina Bastian.2020. Pengaruh Sosialisasi Dalam Keluarga Terhadap Perkembangan Anak Usia Dini. vol 2. No. 1. Padang.

Soerjono, 2004.Pendidikan Anak Usia Dini. (Dyah Kumalasari)

Trinataliswati. Perbedaan Kemampuan Bersosialisasi Pada Anak Bersekolah Dengan Riwayat Paud Dan Tanpa Riwayat Paud. Jurnal Keperawatan. Vol 1.No 2. Malang. 